\title{
THE INFLUENCE OF CORPORATE GOVERNANCE, SIZE, GROWTH AND PERFORMANCE TO EXECUTIVE COMPENSATION (STUDY OF INDONESIAN CAPITAL MARKET)
}

\author{
I Gusti Ketut Agung Ulupui \\ Economic and Business, Jakarta State University \\ ulupui@yahoo.com \\ I Gusti Ayu Made Asri Dwija Putri \\ Economic and Business, Faculty of Udayana University \\ igamasri@yahoo.com
}

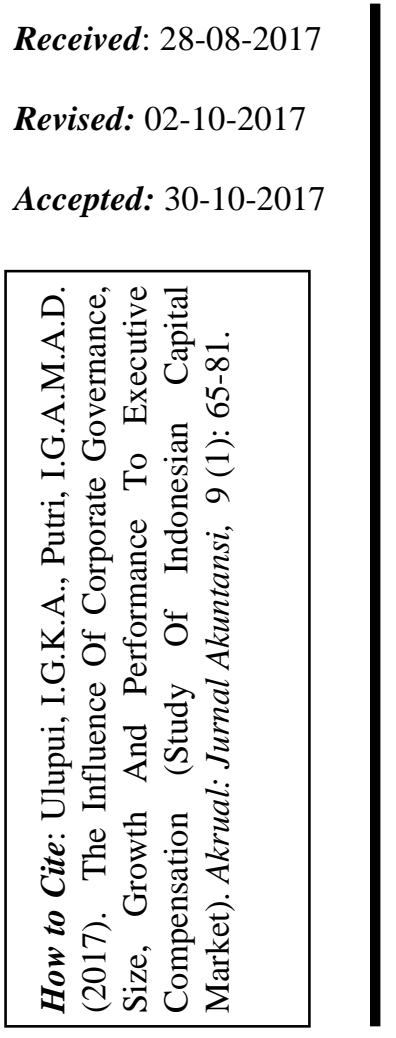

\section{BACKGROUND}

Executive compensation scheme has been commonly used by shareholders as a mean to monitor and motivate managers, in order to improve performance and shareholder value of the company. Agency conflicts often arise between managers and shareholders, and this kind of situation have brought up two theories linking executive compensation with the agency conflict, namely: 1) the optimal contracting 65 approach and 2) managerial power approach. The optimal contracting approach said that compensation is provided in order to measure wether the manager acts solely to improve corporate value (shareholder value). Monitoring and incentive schemes are the effort to reduce agency costs between senior executives and shareholders, especially in public companies. According to the views of Jensen and Meckling (1976) and Guay (1999) that executive 
Ulupui, Putri, The Influence Of Corporate Governance, Size, Growth And...

compensation practices commonly used the optimal contracting approach. The optimal contracting approach consider that senior executives try to maximize shareholder value so that the design of compensation given to executives meet these objectives. In terms of managerial power approach that executive compensation is seen not only as an important instrument to overcome the problems of the agency but also as part of the agency problem itself (Bebchuk and Friend, 2003).

Some other researchers in Asia who studied the relationship between executive compensation and corporate performance, among others, Kato and Long (2004) examine the performance of the company, the Chinese government ownership and executive compensation; and Kato and Kubo (2006) examines the CEO compensation and firm performance in Japan. The research on executive compensation in developing countries such as Indonesia, relatively few. Darmadi (2011) reveals that the compensation structure of listed companies in Indonesia is relatively kept confidential, so that only a little information to determine the factors that influence executive compensation. The research in Indonesia which examines the influence of corporate governance, performance, size, and growth of the company to executive compensation carried out by Mardiyati et al. (2013); Darmadi (2011); Ulupui and Siagian (2010).

The effectiveness of corporate governance can affect the executive compensation determination. There is an opinion stating the effectiveness of corporate governance can be seen from the commissioners who come from outside the company with the assumption that they are more independent than the commissioner who comes from within the company. The effective independent commissioner will monitor their action that leads the efforts to improve the performance of the company. This means that an independent commissioner serves to bridge the desire among shareholders as well (Weir and Laing, 2001). But it is not always the case, as the argument from Jensen (1993) that the outside directors are less effective form of compensation levels, because the commissioner who came from outside the company actually appointed by the CEO which they usually do not want to be in a position opposite to the CEO. In other words, the executive can influence the decision on compensation to be obtained.

While the research of Mardiyati et.al (2013) use institutional investors as a proxy of corporate governance indicates that institutional investors in the Indonesian Capital Market have a positive influence on the executive compensation but not significant. This is presumably because the companies in Indonesia, which have a high institutional ownership perform monitoring more efficient than a lower institutional ownership, so the amount of compensation received by the executives is not so high.

Meanwhile Darmadi (2011) uses the size of the board of commissioners and the proportion of independent commissioner as a 
proxy of the practice of corporate governance to find a positive influence between the size of the board of commissioners and the proportion of independent commissioner on the executive compensation. A study conducted by Ulupui and Siagian (2010) showed that corporate governance which is measured using the index of Indonesian Index Corporate Directorship (IICD) has a negative effect on the executive compensation. It indicates that the better application of the CG companies then the lower (optimal) executive compensation received which means the worse application of $\mathrm{CG}$ then the compensation becomes higher.

The size of the company is one of the factors that may affect the executive compensation. Fernandes (2005) suggested that there is a strong influence between the size of the company with executive compensation. This is in accordance with the findings of Ulupui and Siagian (2010), which also suggests that there is a strong influence between the size of the company with the compensation of directors and commissioners.

Kato and Long (2004) examine the executive compensation in China. This paper was first revealed regarding the executive compensation in companies listed on the China stock exchange that is developing and including as the big eight in the world with a market capitalization exceeding $\$ 550$ billion, finding sales growth was significantly related to executive compensation. The executives in China will be penalized if they make a negative profit but if they make the profits decreased, although the result is still positive they will not be sanctioned as well as even though there is an increase in profit yet they will not be rewarded as well.

Agency conflict intensity will affect the performance of the company. The greater the agency conflict is the lower corporate performance will become (Jensen and Meckling, 1976). This view shows that the application of the structure of the executive compensation in companies affect the agency conflict that ultimately also affecting the performance of the company. Firth et al. (1996) also confirms that the previous year's performance also affect the executive compensation.

Various accounting-based performance measurement used in the benchmarking of the incentive system for executives, among others, return on assets (ROA), and return on shareholders' equity (ROE), the percentage change in profit, and earnings per share targets (Chalmers et al. 2006). ROA has a high correlation with other accounting measures, namely a return on equity (ROE) (Antle and Smith, 1986; Kerr and Kren, 1992). This study uses ROA as a measure of corporate performance. Empirical evidence supports that the board of director's compensation relates to corporate performance (Core et al. (1999); Chalmers et al. (2006); Kato and Long (2004); Kato, Kim and Lee (2004); Kato and Kubo (2006), Ulupui and Siagian, (2010).

Kato, Kim, and Lee (2004) examined executive compensation and firm performance in Korea using the Korean conglomerate company 
Ulupui, Putri, The Influence Of Corporate Governance, Size, Growth And...

(chaebol). This paper provides the first econometric estimation of the relationship of compensation with performance (payperformance) for executives in both the Korean company affiliated with chaebol or not. Corporate governance in Korea and the company's compensation structure in Korea is very different from that in western countries, where cash compensation of Korean executives were significantly related to stock market performance, otherwise the alternative performance measures such as accounting and sales performance play unsignificant role in determining executive compensation in Korea.

A few studies in Indonesia that examines research on executive compensation (Ulupui and Siagian, 2010; Darmadi 2011; Mardiyati, 2013) making this study raising concern as follows:

1. Does the executive compensation policy influenced by the practices of corporate governance?

2. Does the executive compensation policy influenced by the size of the company, growth and performance?

\section{Research Purposes}

The motivation of this study is mainly related to the limitations of the study of the executive compensation at public companies in Indonesian capital market. This study therefore intends to obtain empirical evidence about the influence of corporate governance practices, size, growth, and performance on executive compensation of public companies in Indonesia.
THEORY AND THE DEVELOPMENT OF HYPOTHESIS

\section{Issues of The Agency Problem and Executive Compensation}

The separation between the owner and the management company may rise the agency problems. Agency problems can lead agency cost (Jensen and Meckling, 1976) such as cost of structuring, monitoring, and bonding between the agents and the parties which having different interests. The implications of this conflict according to the agency model which raises the problems on how to determine the policy of agency's compensation.

A compensation is an agency costs that incurred to monitore the agent and resolve the conflict, in which compensation can be determined based on the manager's performance and also the final outcome of the manager to make the financial and investment decisions. The effective monitoring of the agency will improve its ability to manage the company so that the company's performance, the company's value, and the principal welfare will increase.

\section{The Effect Of Corporate Governance On Executive Compensation.}

Compensation is also greatly influenced by the structure of governance because the executive compensation determined by the board as a tool to lead managers toward the best action for shareholders (Chalmers et al, 2006). Gueyle and Elloumi (2001) found that CEOs who have a weak board of directors will receive compensation exceeding the CEO who has a strong board of directors (powerful). While Chalmers et al. (2006) and Core et al. (1999) 
found that corporate governance variable proxied by the board size has a significant positive effect on the total compensation. In the contrary, the research of Ulupui and Siagian (2010) found a negative influence between corporate governance with the compensation of directors and commissioners. This study uses corporate governance index to see the effect of corporate governance on compensation.

This research proposed an alternative hypothesis:

CG has negative effect on the executive compensation.

\section{The Effect of Company Size on Executive} Compensation

Compensation as a control mechanism in achieving good corporate governance and also as a means to reduce the agency conflict can be influenced by the size of the company (Chalmer et al, 2006). Relatively large companies will have a greater ability to pay CEO (Sigler, 2011). Thus the size of the company plays an important role in explaining the compensation (Darmadi, 201; Ulupui and Siagian, 2010; Mardiyati et al., 2013).

This research describes the hypothesis:

Firm size has positive effect on executive compensation.

The Effect of Executive Compensation on Company's Growth

In the principal-agent models, especially for companies that have a chance opportunity to grow, there is the premise that states that if the manager's actions can not be observed perfectly then it can be solved with a variety of incentive's design (Smith and Watts, 1992). Companies with a high growth rate paid greater compensation in the form of total compensation. Likewise, companies that have high growth rates increase the proportion of such contingent compensation in the form of bonuses, stock options and longterm peformance plan (Elloumi and Gueyie, 2001). Chalmers et al. (2006) found a positive effect on the company's growth with total compensation. Ulupui and Siagian (2010) also found a positive effect. Thus, allegedly compensation will be even greater if the growth of the company increases.

Therefore the hypothesis proposed:

The company's growth is positively related to executive compensation.

The Effect of Performance on The Executive Compensation

The agency conflict intensity will affect the performance of the company, the greater the agency conflict, the lower the performance of the company may become, because the agency conflict raises agency costs (Jensen and Meckling, 1976). This view shows that the application of the compensation structure within the company have an influence on the performance of the company. Performance of the company is one of the bases that can be used to measure the achievement of a company in a given period. Kato and Long (2004); Kato and Kubo (2006) Mardiyati el al. (2013), Darmadi (2011), Ulupui and Siagian (2010) have found positive influence between the performance of 
Ulupui, Putri, The Influence Of Corporate Governance, Size, Growth And...

companies with executive compensation. This

study uses a proxy return on assets (ROA) to measure the company's performance.

The description of the hypothesis:

The company's performance has positive effect on executive compensation.

\section{RESEARCH METHODS}

This research was conducted in Indonesia Stock Exchange in Jakarta. While the object of research is executive compensation.

\section{Identification of variables}

The variables in this study consists of the dependent variable and independent variables. The dependent variable is the executive compensation received by executives during the year in the form of cash compensation. The independent variables on this study are the factors that determine the amount of executive compensation such as performance, company size, growth, and corporate governance practices.

\section{Variable Operational Definition}

The variables used in this research; executive compensation variable, CG index, company size, growth and the performance of the company can be explained as following:

\section{Executive Compensation (LNKOM)}

Compensation is measured by the total amount of rupiah received by the executive during the year. The executive compensation data, measured in this research taken from the annual financial statements. The compensation data in the total rupiah has tremendous value compared with other variables. In order to use the application of statistical model therefore the compensation value need to be transformed with the natural logarithm.

\section{Corporate Governance (CG)}

This study uses corporate governance practices variable, that is measured by the index of corporate governance which is obtained from the survey conducted by the Indonesian Institute for Corporate Directorship (IICD). IICD's survey conducted regarding the five things: $A$. The rights of shareholders are given a weighting of 20\%; B. equal treatment for all shareholders were given a weighting of $15 \%$; C. The role of stakeholders which is weighted $15 \%$; D. Disclosure and transparency which is weighted $25 \%$; E. The role and responsibilities of the Commissioner was given a weighting of $25 \%$.

\section{Company Size}

The size of the company (LNSIZE) is measured by the value of the natural logarithm of the total assets of the company.

\section{Company Growth}

The growth of companies (PERTUM) is measured by the rate of changes of the company's sales.

\section{Performance}

We used financial performance in the period before compensation was given. The company's financial performance is measured by looking at the ratio of corporate accounting namely return on assets (ROA): Net profit before tax / assets of the company $i$ at one period before executive compensation granted.

\section{Types and Sources of Data}

The type of data used is quantitative data and the source of data used is secondary data. Those data are compensation data, the economic 
determinants (size, growth, and performance) derived from the financial statements of companies listed on the Indonesian Stock Exchange and $\mathrm{CG}$ index derived from the Indonesian Institute for Corporate Directorship (IICD).

\section{Determination of Sample}

The population of this study is including all of go public companies whose shares are listed on the Indonesian Stock Exchange (IDX). The determination of the samples using judgment sampling; the samples must be publicly traded company which are listed on the Indonesian Stock Exchange; they have to report the executive compensation data in their financial statements and also have to be a part of the research's subject of IICD. The observation period is from 2009-2011.

\section{The Data Collection Methods}

The data collection method is means how to obtain the data. In this study, to get the data we observe the financial statements data of the companies listed on the Indonesian Stock Exchange from 2009-2011 by downloading it from www.idx.com.

\section{The Data Analysis}

Hypothesis testing is done by using a multiple regression model.

$\mathrm{LNKOM}_{\mathrm{it}}=\mathrm{a} 0+\mathrm{b} 1 \mathrm{CG}_{\mathrm{i}, \mathrm{t}-1}+\mathrm{b} 2 \mathrm{LNSIZE}_{\mathrm{i}, \mathrm{t}-1}+$ b3PERTUM $\mathrm{i}_{\mathrm{t}, \mathrm{t}-1}+\mathrm{b}_{\mathrm{ROOA}} \mathrm{R}_{\mathrm{t} \mathrm{t}-1}+\varepsilon_{\mathrm{i}}$

\section{The Data Analysis Techniques}

\section{Descriptive Statistics}

Descriptive statistics is a statistical summary formed by tabulation and / or graphics, based on the groups of selected variables (Agung, 2011).
The summaries of descriptive statistics describe the main characteristics of the variables and the form of central tendency, maximum and minimum, standard deviation.

\section{Regression Analysis}

The structure of the data used in this study is pooled data, including the whole company on the Indonesian Stock Exchange which have executive compensation data from 2009-2011. This study is analyzed using multiple linear regression and used Eviews 6 and SPSS 15. Its also estimate the Goodness of Fit of the model with determination test $\left(\mathrm{R}^{2}\right)$ and significance test (F).

\section{Classical Assumption Test}

The classical assumption test is used to make the regression model estimation is feasible therefore the regression model have to comply the assumptions set out in order to meet the values of coefficients are not biased. The assumptions are:

a) the dependent variable and independent variables have a linear relationship or straight line.

b) dependent variable should be continuous, or at least scale interval.

c) The diversity of the difference between observation and prediction value should be the same for all values of Y. Approximately, so (Y-Y ') should be roughly equal for all values of $Y^{\prime}$. If this condition does not met, then called heteroskedasticity and residual calculated from (Y-Y ') must be spread normal with an average of zero. 
Ulupui, Putri, The Influence Of Corporate Governance, Size, Growth And...

d) Observations following variables should be uncorrelated. Violations of this assumption is called autocorrelation which usually occurs in time series data.

e) The lack of a perfect correlation between independent variables with each other. If this assumption is violated then called multicoliniearity (Sanusi, 2011).

\section{THE RESULT}

\section{Samples}

This study used a sample of public companies listed on the Indonesian Stock Exchange from 2009 to 2011. Basic considerations in choosing the sample use purposive sampling. First, authors search the companies listed on the Indonesian Stock Exchange from 2009-2011, and it must be include in the survey of IICD, and had reveal the executive compensation in their financial statements from 2009-2011. Second, the selected companies must complete financial data for the period.

Table 2. Descriptive Test Result

\section{Table 1. List of Samples}

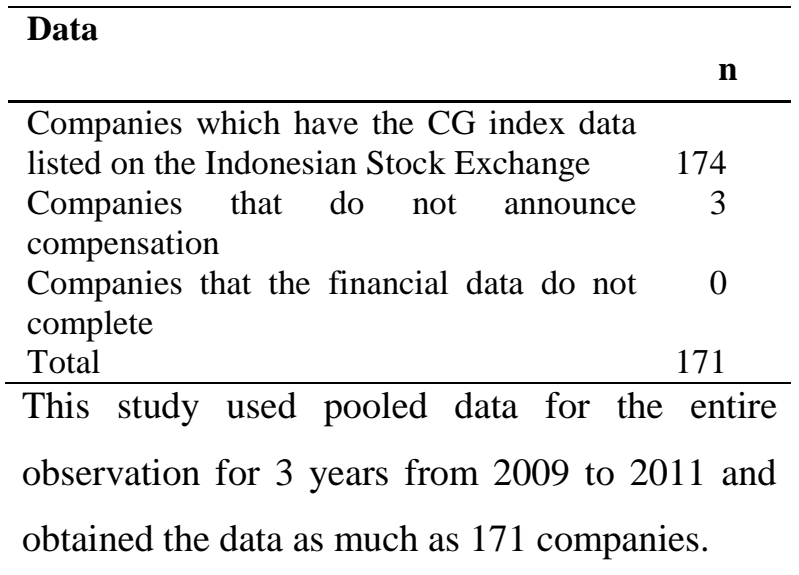

\section{Data Analysis Techniques}

The structure of the data used in this study is pooled data. This study estimating the Goodness of Fit of the model with determination test $\left(\mathrm{R}^{2}\right)$ and the degree of significancy test ( $\mathrm{F}$ test) and the data is run with Eviews 7 and SPSS 15.

\section{Descriptive statistics}

Descriptive statistics is a statistical summary in a tabulation form, based on the groups selected variables (Agung, 2011). The descriptive statistics result can be seen in table 2:

\begin{tabular}{|c|c|c|c|c|c|}
\hline & $\mathbf{N}$ & Minimum & Maximum & Mean & $\begin{array}{r}\text { Std. } \\
\text { Deviation }\end{array}$ \\
\hline $\begin{array}{l}\text { LNKOM } \\
\text { (million) }\end{array}$ & 171 & 1.090 & 891.634 & 61.65 & 142.95 \\
\hline $\begin{array}{l}\text { CG } \\
\text { LNSIZE }\end{array}$ & 171 & 0,24 & 0,89 & $\begin{array}{l}0,72 \\
52.66\end{array}$ & $\begin{array}{l}0,12 \\
98.015\end{array}$ \\
\hline (million) & 171 & 268.013 & 551.891 .704 & 9.231 & 0.888 \\
\hline PERTUM & 171 & $-0,88$ & 3,75 & 0,16 & 0,44 \\
\hline ROA & 171 & $-0,17$ & 0,41 & 0,08 & 0,10 \\
\hline
\end{tabular}

Source: Data Processing

\section{Explanation of the table:}

Descriptive statistics in Table 2 illustrates the variable of executive compensation as the dependent variable and the independent variable are the governance's practice and economic determinants which consist of size, growth, and performance of the company. Mean data and the standard deviation is used to determine the fluctuations of each variables tested, while the data also shows the range of minimum and 
maximum data.

The tables above draw some conlusion that executive compensation for the 171 companies selected as samples, the maximum compensation is Rp891.634 million which is owned by PT. Unilever Tbk. and the minimum compensation Rp1.090 million is owned by the company Millenium Pharmacon International Tbk. On average executive compensation for the entire sample selected is Rp61.654 million with a standard deviation is Rp142.956 million. A fairly high standard deviation indicates high enough gap between the lowest and the highest compensation.

CG index for the 171 companies surveyed, on average, showed a value of $72 \%$ with a maximum value $89 \%$ is owned by Antam (ANTM) and the minimum value $24 \%$ is owned by the company PT Gudang Garam (GGRM). The average index of $72 \%$, indicating that on average the $\mathrm{CG}$ practices in Indonesia has sufficient (fair) criteria leads to good criteria.

The size of the company showed a minimum value Rp268.013 million owned by Millenium Pharmacon International Tbk and the maximum value is Rp551.891.704 million owned by Bank Mandiri and the average size of the company is USD 52,669,231 million. The standard deviation is approaching twice of the mean value indicates there is a high gap between large and small companies. The range of size values are too high compare with another independent variables value, therefore the size values need to be transformed into natural logarithm values as the application of statistical models. The growth of the company for the entire selected sample average is 0.16 . With a minimum value of -0.88 times owned by PT Intaco Penta Tbk and a maximum value of 3.75 times owned by PT Lipo Karawaci Tbk. The standard deviation of 0.44 was close to three times the average growth rate shows a high variance between high and low growth companies.

The table above shows the performance variable is the performance of the company's accounting ROA were assessed with an average of around $8 \%$ and the maximum value is $41 \%$ owned by PT Unilever while the minimum value is $-17 \%$ owned by Energi Mega Persada Tbk. The standard deviation of $10 \%$ indicates there is a gap between the company with low- and highperforming.

\section{Data Analysis}

\section{Determination Test Results}

Table 3 showed Adjusted R-squared $\left(\mathrm{R}^{2}\right)$ 0.519332, which means the variation of independent variables on the dependent variables as much as $52 \%$ can be explained by corporate governance and the economic determinants (ROA, Company Size and Growth) and the rest influenced by the other variables.

\section{F Test Results}

The statistical results showed the value of $F$ test $p$ $=0.0000<0.01$, the hypothesis can be accepted that all the independent variables feasible to describe the independent variables analyzed. In the other words at a significance level of $1 \%$ means that all the independent variables used in the model can explain the dependent variable together. 
Ulupui, Putri, The Influence Of Corporate Governance, Size, Growth And...

\section{Classical Assumption Test}

Regression models used for estimation is a regression model that meets the classical assumption or it free from multicollinearity, autocorrelation and heteroscedasticity problems.

\section{Multicollinearity Test}

Ghozali (2012: 95) states that multicollinearity test aims to test whether the regression model found a correlation between the independent variables. One of the criteria for detecting the presence or absence of multicollinearity problems in a regression can be seen from the VIF. If the VIF value is not more than 10 and the value of Tolerance is not less than 0.1 then the model can be said to be free from multicollinearity.

\section{Heteroskedasticity test}

Heteroskedasticity test aims to test whether the regression model occurred inequality residual variance from one observation to another observation. If the variance of the residuals of the observations of the other different, then called heteroscedasticity. According the SPSS's calculation for detecting the presence of heteroskedasticity can be seen whether or not the level of significancy of each variable significantly below from 5\% (Ghozali, 2012: 125).

Heteroscedaticity indicate that the residual variance of any error or heterogeneous, which means breaking the classical assumption requires that residuals should be homogeneous. The tests to detect heteroskedasticity can be done with formal tests and graphical way. In this study, the heteroscedasticity test detects residual pattern through a graph, namely, by making the plot between the dependent variable and the residuals. If the residuals have the same variance (homoscedaticity) then we do not have a definite pattern of residuals. Conversely, if the residual has heteroscedasticity properties, residuals will show a certain pattern. Heteroscedasticity can be seen from the plot in the graph between residual and dependent variable. Formal test to detect the presence of heteroscedasticity was conducted by White. The hypothesis testing in White are as follow:

H0: There is no heteroscedasticity

Ha: There is heteroscedasticity

The basic rejection of the hypothesis above is by comparing the value of $\mathrm{Chi}-\mathrm{Sq}$ calculate the value of $\mathrm{Chi}-\mathrm{Sq}$ table. Chi-Sq counts the value from the output of the program EViews 7 which can be seen in the value Obs* $\mathrm{R}$-Squared. If the value of Chi-Sq counted is greater than the value of Chi-Sq tabled then we reject the null hypothesis (H0). Conversely, if the value of Chi-Sq counted is smaller than the value of Chi-Sq tabled then we fail to reject the null hypothesis (H0).

Moreover, it can also be seen from the probability of Chi-Square on the output of Eviews program, if the value is less than the value of significant level then we reject the null hypothesis ( $\mathrm{H} 0)$. Based on the test have done, it appears that the test results show a smaller probability of $\alpha=5 \%$. It concludes that there is sufficient evidence to suggest that is no heteroscedasticity.

\section{Autocorrelation Test Results}

The result of autocorrelation test by using the method of Lagrange Multiplier (LM). Visible value Obs * $\mathrm{R}$-Squared has a probability of 
0.3230. The probability shows can not reject the hypothesis, which states:

H0: there is no correlation

H1: there is correlation

In the equations used in the LM Test to test the visible residual autocorrelation was not significantly affected by the residual variable residual lag 1 and lag 2 also by variable Lnsize, Pertum, ROA and CG. Then the LM test results are not significant. Thus concluded the model already contains no autocorrelation.

\section{The t-Test Results}

The results of $\mathrm{t}$ test using Multiple Linear Regression analysis which processed by Eviews 7 can be seen in Table 3 .

The equation obtained is:

$\mathrm{LNKOM}=8.02+0.50 * \mathrm{LNSIZE}+4.61 * \mathrm{ROA}-$ $0.17 *$ PERTUM $+0.30 *$ GCG

Table 3. The Result of Regression Analysis

\begin{tabular}{lllll}
\hline \multicolumn{2}{l}{ Dependent Variable: } & LNKOM & & \\
Variable & Coefficient & Std. Error & t-Statistic & Prob. \\
\hline CG & 0.301207 & 0.538240 & 0.559615 & 0.5765 \\
LNSIZE & 0.503974 & 0.041871 & 12.03632 & 0.0000 \\
PERTUM & -0.173714 & 0.149165 & -1.164582 & 0.2459 \\
ROA & 4.615618 & 0.662217 & 6.969943 & 0.0000 \\
C & 8.023457 & 1.297937 & 6.181700 & 0.0000 \\
\hline & & & & \\
Adjusted R-squared & 0.519332 & & & \\
F-statistic & 46.91858 & & & \\
Prob(F-statistic) & 0.000000 & & & \\
Durbin-Watson stat & 2.025382 & & & \\
Source: Data Processing & & &
\end{tabular}

\section{DISCUSSION}

This study used multiple linear regression analysis to see the effect of variable CG, company size, growth and performance on executive compensation.

The influence of corporate governance on executive compensation

Allegations that influence the corporate governance of the executive compensation is not supported by the data. This study shows a positive relationship corresponding direction of research Chalmers et al (2006) and Core et al. (1999) that is more powerful $\mathrm{CG}$ then executive compensation increased, but not significantly. This study therefore also different from Ulupui research and Siagian (2010) who found a negative influence between CG with executive 75 compensation.

\section{The influence company size on executive compensation}

Compensation as a control mechanism in achieving good corporate governance and as a means to reduce the agency conflict can be influenced by the size of the company (Chalmer et al, 2006). Relatively large companies will have a greater capability in carrying out payment to the CEO (Sigler, 2011). Thus the size of the company plays an important role in explaining to do with compensation (Darmadi, 2011). The results of hypothesis 2 shows that firm size has significant positive effect to the executive compensation, with the level of $\mathrm{p}$-value $<0.05$. These results are consistent with the studies of Darmadi 2011, Ulupui and Siagian, 2010 and Mardiyati et al., 
Ulupui, Putri, The Influence Of Corporate Governance, Size, Growth And...

2013. The coefficient of the size of the company amounted to 0.503974 indicate any changes in assets of 1 percent, the compensation will increase by 0.5 percent.

\section{The effect of growth on executive compensation}

A statement that the company with a high growth rate pay higher compensation in this study does not prove because the p-value shows above 5\% and it is not significance and also the direction of hypothesis do not match with the predictions. Another word, the data do not support the hypothesis.

This can occur because the context of this study are in the last crisis period is 2009 to 2011. The impact of this crisis the economic growth is slowing, which could be detected in the delta ratio of sales value as a proxy for growth showed a negative value. These results reject the research of Chalmer (2006); Ulupui and Siagian (2010) who found a positive effect on the company's growth with total compensation.

\section{The influence of ROA on executive compensation}

$\mathrm{t}$ test results it appears that ROA significant positive effect on executive compensation with p-values $<0.05$. Coefficient values of ROA is 4.61 can be interpreted by taking into account other independent variables when ROA companies increased one percent, the compensation increased by four percent. This is consistent with numerous studies Kato and Long (2004); Kato and Kubo (2006) Mardiyati el al. (2013), Dharmadi (2011), Ulupui and Siagian (2010). Application of the compensation structure within the company have an influence on the performance of the company. Performance of the company is one of the bases that can be used to measure the achievement of a company in a given period.

Results of this study are influenced by the period of the research conducted is in the last period of crisis. Although the average CG index showed that the samples had an average of approaching pretty good, but the crisis led the compensation was not adjusted despite good corporate governance. This is to avoid too high expenses incurred as a result will affect the overall performance of the company. So that $\mathrm{CG}$ role here is still at the level of implementation of the rules but have not yet applied either for executive compensation.

\section{CONCLUSIONS, IMPLICATIONS, AND LIMITATIONS}

Hypothesis Test results showed that the only performance and size variables that have significant positive effect on executive compensation. While the growth variables are not supported by data as well as corporate governance variables.

The implications of this study for subsequent research is expected to add market variables as independent variables like stock returns and beta to determine whether the performance of external influence on executive compensation. Likewise, subsequent research can add another factor, especially corporate governance ownership structure. Besides expanding the use of research methods using panel data analysis with pooled least squared (PLS) because not all the companies announced 
a total compensation at the company.

Limitations of this study are as follows, this study only use companies that are used as samples by Indonesian Institutes of Corporate Directorship. Total compensation used is the total cash compensation, as well as still mingled with the value of the compensation of the Board of commissioners.

\section{REFERENCE}

Allouche, J., Amann, B., Jaussaud, J., \& Kurashina, T. (2008). The impact of family control on the performance and financial characteristics of family versus nonfamily businesses in Japan: a matchedpair investigation. Family Business Review, 21(4),315-329.

https://doi.org/10.1177/089448650802100 $\underline{40104}$

Alchian, A. A., \& Demsetz, H. (1972). Production, information costs, and economic organization. The American economic review, 62(5), 777-795.

https://doi.org/10.1017/cbo978051181741 0.015

Antle, R., \& Smith, A. (1986). An empirical investigation of the relative performance evaluation of corporate executives. Journal of Accounting Research, 1-39.

https://doi.org/10.2307/2490920

Zhuang, J., Edwards, D., \& Capulong, M. V. A. (2001). Corporate Governance \& Finance in East Asia: A Study of Indonesia, Republic of Korea, Malaysia, Philippines and Thailand. Asian Development Bank.. Contained on: https://aric.adb.org

Agung, I. G. N. (2011). Cross Section and Experimental Data Analysis Using EViews. John Wiley \& Sons.

Bebchuk, L. A., Fried, J. M., \& Walker, D. I. (2002). Managerial power and rent extraction in the design of executive compensation (No. w9068). National bureau of economic research. DOI: https://doi.org/10.3386/w9068
Arye Bebchuk, L., \& Fried, J. M. (2003). Executive compensation as an agency problem. The Journal of Economic Perspectives, 17(3), 71-92.

DOI:https://doi.org/10.1257/08953300376 9204362

Brick, I. E., Palmon, O., \& Wald, J. K. (2006). CEO compensation, director compensation, and firm performance: Evidence of cronyism?. Journal of Corporate Finance, 12(3), 403423.https://doi.org/10.1016/j.jcorpfin.2005 .08 .005

Bunkanwanicha, P., Gupta, J., \& Rokhim, R. (2008). Debt and entrenchment: Evidence from Thailand and Indonesia. European Journal of Operational Research, 185(3), 1578-1595.

https://doi.org/10.1016/j.ejor.2006.08.025

Chalmers, K., Koh, P. S., \& Stapledon, G. (2006). The determinants of CEO compensation: Rent extraction or labour demand?. The british accounting review, 38(3), 259-275.

https://doi.org/10.1016/j.bar.2006.01.003

Claessens, S., Djankov, S., \& Lang, L. H. (2000). The separation of ownership and control in East Asian corporations. Journal of financial Economics, 58(1), 81112.https://doi.org/10.1016/s0304405x(00)00067-2

Claessens, S., \& Fan, J. P. (2003). Corporate governance in Asia: A survey. https://doi.org/10.2139/ssrn.386481

Claessens, S., Simeon, D., \& Larry H. P. Lang. (1999a). Who Controls East Asian Corporations. Working Paper, World Bank, Washington DC.

Claessens, S., Djankov, S., Fan, J. P., \& Lang, L. H. (1999). Expropriation of minority shareholders: Evidence from East Asia (pp. 461-498). Washington, DC: World Bank.

Claessens, S., Djankov, S., \& Lang, L. H. (2000). The separation of ownership and control in East Asian corporations. Journal of financial Economics, 58(1), 81-112. https://doi.org/10.1016/s0304$\underline{405 x(00) 00067-2}$ 
Ulupui, Putri, The Influence Of Corporate Governance, Size, Growth And...

Claessens, S., Djankov, S., Fan, J. P., \& Lang, L. H. (2002). Disentangling the incentive and entrenchment effects of large shareholdings. The journal of finance, 57(6), 2741-2771. https://doi.org/10.1111/1540-6261.00511

Thomas, C. (2004). Theories of Corporate Governance, The Philosophical Foundation of Corporate Governance. London and New York: Routledge, ISBN $X, 41532307$.

Conyon, M. J., \& Murphy, K. J. (2000). The prince and the pauper? CEO pay in the United States and United Kingdom. The Economic Journal, 110(467), 640671.https://doi.org/10.1111/14680297.00577

Copeland, T. E., Weston, J. F., \& Shastri, K. (2005). Financial theory and corporate policy. Paerson Addison Wesley. Fourth Ed. USA.

Core, J. E., Holthausen, R. W., \& Larcker, D. F. (1999). Corporate governance, chief executive officer compensation, and firm performance. Journal of financial economics, 51(3), 371-406.

https://doi.org/10.1016/s0304405x(98)00058-0

Cyert, R. M., Kang, S. H., \& Kumar, P. (2002). Corporate governance, takeovers, and topmanagement compensation: Theory and evidence. Management Science, 48(4), 453-469.

https://doi.org/10.1287/mnsc.48.4.453.205

Darmadi. (2011). Determinant of Execuitve Compensation. Indonesian Journal of Accounting Research.

Du, J., \& Dai, Y. (2005). Ultimate corporate ownership structures and capital structures: Evidence from East Asian economies. Corporate Governance: An International Review, 13(1), 60-71.

https://doi.org/10.1111/j.14678683.2005.00403.x

Elloumi, F., \& Gueyié, J. P. (2001). CEO compensation, IOS and the role of corporate governance. Corporate Governance: The international journal of business in society, 1(2), 23-33. https://doi.org/10.1108/eum000000000548 $\underline{7}$
Faccio, M., \& Lang, L. H. (2002). The ultimate ownership of Western European corporations. Journal of financial economics, 65(3), 365-395. https://doi.org/10.1016/s0304405x(02)00146-0

Fama, E. F. (1980). Agency Problems and the Theory of the Firm. Journal of political economy, 88(2), 288-307. https://doi.org/10.1086/260866

Fama, E. F., \& Jensen, M. C. (1983). Separation of ownership and control. The journal of law and Economics, 26(2), 301-325. https://doi.org/10.1086/467037

Fernandes, N. (2008). EC: Board compensation and firm performance: The role of "independent" board members. Journal of imultinational financial management, 18(1), 30-44. https://doi.org/10.1016/j.mulfin.2007.02.0 03

Firth, M., Fung, P. M., \& Rui, O. M. (2006). Corporate performance and CEO compensation in China. Journal of Corporate Finance, 12(4), 693-714. https://doi.org/10.1016/j.jcorpfin.2005.03. $\underline{002}$

Gaver, J. J., \& Gaver, K. M. (1993). Additional evidence on the association between the investment opportunity set and corporate financing, dividend, and compensation policies. Journal of Accounting and economics, 16(1-3), 125-160. https://doi.org/10.1016/01654101(93)90007-3

Gaver, J. J., \& Gaver, K. M. (1995). Compensation policy and the investment opportunity set. Financial management, 19-32.https://doi.org/10.2307/3665874

Goldberg G.L \& Todd L.Idson. 1995. Executive Compensation and Agency Effects. The Financial Review, Vol 30. No. 2 May. Pp. 313-335 https://doi.org/10.1111/j.15406288.1995.tb00835.x

Gomez-Mejia, L. R., Tosi, H., \& Hinkin, T. (1987). Managerial control, performance, and executive compensation. Academy of Management journal, 30(1), 51-70. https://doi.org/10.2307/255895 
Gordon E. A., Henry, E., \& Palia, D. (2004). Related Party Transactions: Associations with Corporate Governance and Firm Value. Dipresentasikan pada 2004 American Accounting Association Annual Meeting dan 2004 European Finance Association Annual Conference. Download from: http://www. nd. edu/ carecob/workshops/Gordon.pdf

Samuael, G. R. (1997). The Role of Risk in Executive Compensation. Journal of Management. Diakses dari http://findarticle.com.

Gregg,P., Jewell, S., \& Tonks, I. (2005). Executive Pay and Performance in the UK 1994-2002. CMPO Working Paper No. 05/122 ISSN 1473-625X

Gueyle \& Elloumi. (2001). CEO compensation, IOS and Role of Corporate Governance. Indonesian Institute of Corporate Directorships (IICD). 2004. http://info @iicd.co.id.Jakarta

Baek, J. S., Kang, J. K., \& Park, K. S. (2004). Corporate governance and firm value: Evidence from the Korean financial crisis. Journal of Financial economics, 71(2), 265-313.

https://doi.org/10.1016/s0304405x(03)00167-3

Jensen, M. C. (2003). A theory of the firm: governance, residual claims, and organizational forms. Harvard University Press.

Jensen, M. C., \& Meckling, W. H. (1976). Theory of the firm: Managerial behavior, agency costs and ownership structure. Journal of financial economics, 3(4), 305-360.

https://doi.org/10.1016/0304405x(76)90026-x

Jensen C.M. dan Murphy K.J. (1990). Performance Pay and Top-Management Incentives. Journal of Political Economy, April, vol, no. 2, pp. 225-264.

Jensen C.M., Kevin J.Murphy, Erick G.Wruck. (2004). Remuneration: Where We've Been, How We Got to Here, What are the Problems, and How to Fix Them. Harvard. NOM Working Paper No. 04-28; ECGIFinance Working Paper No. 44/2004

Jensen, M. C., \& Murphy, K. J. (1990). Performance pay and top-management incentives. Journal of political economy, 98(2), 225-264. https://doi.org/10.1086/261677

Kato, T., \& Long, C. (2004). Executive compensation, firm performance, and state ownership in China: evidence from new panel data. The William Davidson Institute Working Paper Number 690.

Kato, T., \& Kubo, K. (2006). CEO compensation and firm performance in Japan: Evidence from new panel data on individual CEO pay. Journal of the Japanese and International Economies, 20(1), 1-19. https://doi.org/10.1016/j.jjie.2004.05.003

Kato Takao, Woochan Kim, \& Ju Ho Lee. (2004). Executive Compensation, Firm Performance, and Chaebols in Korea: Evidence From New Panel Data. The William Davidson Institute Working Paper.

Khanna, T., \& Palepu, K. (1997). Why focused strategies may be wrong for emerging markets. Harvard business review, 75(4), 41-48.

Khana Tarun and Krishna Palepu. 1999. Emerging Market Business Groups, Foreign Investors, and Corporate Governance. National Bureau of Economics Research Working Paper. http://www.nber.org/papers/w6955.

L Shleifer, A., La Porta, R., \& Lopez-DeSilanes, F. (1999). Corporate ownership around the world. Journal of Finance, 54(2), 471-517. https://doi.org/10.1111/0022-1082.00115

Rafael, L. P., Lopez-de-Silanes, F., Sjleifer, A \& Vishny, R. (2002). Investor Protection and Corporate Governance.

Lambert, R. A., \& Larcker, D. F. (1985). Golden parachutes, executive decision-making, and shareholder wealth. Journal of Accounting and Economics, 7(1), 179203.https://doi.org/10.1016/01654101(85)90036-9

Lippert, R. L., \& Rahman, M. (1999). Multinationality, CEO compensation, and corporate governance: Some empirical evidence. Managerial finance, 25(10), 112.https://doi.org/10.1108/030743599107 66181 
Ulupui, Putri, The Influence Of Corporate Governance, Size, Growth And...

Lukviarman N. (2004). Ownership Structure and Firm Performance: The Case of Indonesia. Thesis of Doctoral Degree of Business Administration of Curtin University.

Conyon, M. J., \& Murphy, K. J. (2000). The prince and the pauper? CEO pay in the United States and United Kingdom. The Economic Journal, 110(467), 640-671. https://doi.org/10.1111/1468-0297.00577

Megginson L. W. (1995). Corporate Finance Theory. Addison - Wesley. Educational Publisher Inc. California

Mehran, H. (1995). Executive compensation structure, ownership, and firm performance. Journal of financial economics, 38(2), 163-184.

https://doi.org/10.1016/0304405x(94)00809-f

Myers S.C. (1977). Determinants of Corporate Borrowing. Journal of Financial Economics.July. 147-175. https://doi.org/10.1016/0304405x(77)90015-0

Milkovich T. G. \& Jerry M. N. (2002). Compensation. McGraw-Hill Irwin. Sevent Edition. International Edition. IBSN 0-07-112334-5

Murphy, K. J. (1985). Corporate performance and managerial remuneration: An empirical analysis. Journal of accounting and economics, 7(1-3), 11-42. https://doi.org/10.1016/01654101(85)90026-6

Nachrowi Dj.N. \& Hardius U. (2002). Penggunanaan Teknik Ekonometri. PT RajaGrafindo Persada. Jakarta.

Pavlik L. E. \& Belkoui, A. 1991. Determinants of Executive Compensation. Quorum Books. New York.

Perry, T., \& Zenner, M. (2001). Pay for performance? Government regulation and the structure of compensation contracts. Journal of Financial Economics, 62(3), 453-488.

https://doi.org/10.1016/s0304405x(01)00083-6

Ryan, H. E., \& Wiggins, R. A. (2004). Who is in whose pocket? Director compensation, board independence, and barriers to effective monitoring. Journal of Financial Economics, 73(3), 497-524. https://doi.org/10.1016/j.jfineco.2003.11.0 $\underline{02}$
Cyert, R. M., Kang, S. H., \& Kumar, P. (2002). Corporate governance, takeovers, and topmanagement compensation: Theory and evidence. Management Science, 48(4), 453-469.

https://doi.org/10.1287/mnsc.48.4.453.205

Rokhim R. (2006). Ownership Concentration and Expropriation of Entrepreneurial Resource. Working paper presented at Euroseas 2004, Doctoral Journey of ADRES - Ecole Polytechnique-Paris, $2^{\text {nd }}$ International Conference of the Japan Exonomic Policy Association.

Sato, Y. (2004). Corporate governance in Indonesia: A study on governance of business groups. Asian Development Experience, 2, 88-136.

Setiawati L., Saputro A.J. (2003). Kesempatan Bertumbuh dan Manajemen Laba: Uji Hipotesis Political Cost. SNA VI, Surabaya.

Mardiyati, U., Devi, M. S., \& Suherman, S. (2017). Pengaruh Kinerja Perusahaan, Corporate Governance, Dan Shareholder Payout Terhadap Kompensasi Eksekutif Studi Kasus Pada Perusahaan Non Financial Yang Terdaftar Di Bursa Efek Indonesia Tahun 2007-2010. JRMSIJurnal Riset Manajemen Sains Indonesia, 4(2), 167-183.

Sigler, K. J., \& Carolina, N. (2011). CEO compensation and company performance. Business and Economics Journal, 31(1), 1-8.

Sloan, R. G. (1993). Accounting earnings and top executive compensation. Journal of accounting and Economics, 16(1-3), 55100.

https://doi.org/10.1016/01654101(93)90005-Z

Smith Jr, C. W., \& Watts, R. L. (1992). The investment opportunity set and corporate financing, dividend, and compensation policies. Journal of financial Economics, 32(3), 263-292. https://doi.org/10.1016/0304405x(92)90029-w

Smith, P.G. (2005). How Important are Systematic Risk and Firm Size to Executive Compensation? It's All Relative. Departement of Banking and Finance, Terry College and Business, University of Georgia, Athens. 
AKRUAL: Jurnal Akuntansi, volume 9, nomor 1, Oktober 2017, (65-81)

Kaplan, S. N. (1994). Top executive rewards and firm performance: A comparison of Japan and the United States. Journal of political Economy, 102(3), 510-546. https://doi.org/10.1086/261944

Syakhroza A. (2004). Model Komisaris untuk Efektivitas GCG di Indonesia. Usahawan No. 05 TH XXXIII.

Tabalujan, B. S. (2001). Why Indonesian Corporate Governance Failed-Conjectures Concerning Legal Culture. Colum. J. Asian L., 15, 141. https://doi.org/10.2139/ssrn.306120

Teen Y.M. (2006). From Conformance to Performance Best Corporate Governance Practices for Asian Companies. Mc GrawHill. Singapore
Ulupui \& Siagian. (2010). Corporate governance, struktur kepemilikan, dan kompensasi Kompensasi eksekutif perusahaan-perusahaan di BEI. Journal of Finance and Banking.

Yeh, Y. H., Lee, T. S., \& Woidtke, T. (2001). Family control and corporate governance: Evidence from Taiwan. International Review of finance, 2(1-2), 21-48. https://doi.org/10.1111/1468-2443.00014

Zhou, X. (2000). CEO pay, firm size, and corporate performance: evidence from Canada. Canadian Journal of Economics/ Revue canadienne d'économique, 33(1), 213-251.

https://doi.org/10.1111/0008 4085.00013 